\title{
Cultural Revolution on the Border: Yunnan's 'Political Frontier Defence' (1969-1971)
}

Michael Schoenhals

\begin{abstract}
This paper addresses an important but so far neglected episode in the post1949 history of China - the impact of the so-called 'Cultural Revolution' on the country's ethnic minority populations. Specifically, it attempts to deal with the movement as it unfolded in the province of Yunnan where, at one stage, it became an attempt by a political leadership in the provincial capital, dominated by military officers and supported by members of the central authorities in Beijing, to alter the landscape of the ethnic minority populations along the frontier. Using information culled from local histories and contemporary sources, the paper traces the history of what even by the standards of the Cultural Revolution (1966-76) came to be regarded as an exceptionally flawed and counterproductive policy. It foregrounds the human cost of its implementation and, for the first time, goes some way towards explaining - in more than simply general terms of labels like 'excesses' and 'ultra-leftism' - the trauma of those who survived it, a trauma that to this day still lingers in popular memory. ${ }^{1}$
\end{abstract}

\section{Introduction}

During the 'Great Proletarian Cultural Revolution', China's southern frontier - where the province of Yunnan borders on Vietnam, Laos and Burma - witnessed the implementation of something called a 'political frontier defence' (zhengzhi bianfang) (PFD). As part of the Cultural Revolution, the PFD has left no traces in the works of historians concerned with national-level events and developments, nor has it figured in social science scholarship concerned with the organization of political power and its consequences in the 'Maoist system' (Barnouin and Yu 1993; MacFarquhar and Fairbank 1991; Yan and Gao 1996). The probable explanation for this is not that the PFD was intrinsically insignificant, because it most certainly was not. It is however likely that the PFD has been overlooked because it affected what for centuries has been viewed by Chinese and foreigners alike as a somewhat remote corner of the Middle Kingdom. Physical distance still matters in the scheme of things, and Yunnan (literally 'south of the clouds') undoubtedly qualifies as 
well beyond the periphery, if one's geographical or intellectual vantage point is - as is most often the case - China's national capital.

The present paper attempts to tell the history of the remarkable mix of destructive policies and practices through which the Cultural Revolution came to impact on the ethnic minority populations along the provincial border. Pulling together data culled from contemporary sources and from local gazetteers (county histories) published since the end of the 1980s, it seeks to show how and why the PFD became a systematic and near-total negation of an entire spectrum of approaches toward the administration of the ethnic minority population on the frontier practised by Yunnan's provincial government prior to the start of the Cultural Revolution in 1966. This paper will argue that in responding to increasingly vocal calls from the central government for (in the words of Mao Zedong) 'destruction, without which there can be no construction', local authorities with the help of the PFD brought to a close more than a decade and a half of co-optation and occasional positive discrimination. ${ }^{2}$

The PFD directly affected the lives of roughly 3 million people. To the non-Han majority of these residents of Yunnan's frontier counties, it must have appeared even harsher than the policies and practices already shaping the lives of ordinary Chinese further inland, simply because it telescoped into one massive onslaught what in the provincial capital, the rest of Yunnan and indeed most of China had amounted to a succession of political movements punctuated by periods of relative calm. The PFD was tantamount to land reform, thought reform, the formation of People's Communes, 'Four Cleanups', 'anti-revisionism', etc. all rolled into one. It represented a 'big bang' approach to social transformation. It sought to mould, as quickly as possible and by brute force if necessary, every member of the 'people' (the total population minus the class enemy) along the frontier into a corporalization of the communist party's 'lofty humans' (gaoji de ren) - the ideal beings that 'we Chinese', in the words of Defence Minister Lin Biao, must become 'if we want to stand at the forefront of the world, not resign ourselves to a backward position ... [and] raise the position of our nation' (Lin 1967: 135). The PFD was particularly harsh because in every respect, beginning with culture and ending with economics, Yunnan's frontier population was even further removed from the ideal than the proto-typical inlander. The logic of 'struggle' espoused by the Chinese Communist Party (CCP) dictated that such people, who had further to go, needed to struggle or 'be struggled' harder. 
Ethnicity, in this context, was incidental while class and class alone was fundamental. This was a point that had been driven home to PRC President Liu Shaoqi prior to his fall from grace at the start of the Cultural Revolution, after he had been foolish enough to maintain that human nature and not class was fundamental. Liu had eventually been made to admit to a group of outraged university students that he had been in error (by 'putting the incidental before the fundamental') when he claimed that 'sons and daughters of the exploiting classes and any [members of those classes] ... not yet executed are still human beings' (Lin 1967: 134). Ethnicity, certainly, if not yet humanity, was excluded from that which was fundamental to the PFD. Officially, the word 'minzu' ('ethnicity' or 'nationality' in English) was taboo (MacKerras 2003: 2122). At mass rallies organized by the provincial authorities in Kunming in 1969, hand-picked activists from frontier counties were quoted as saying that 'People of the same class are our only kinsmen, not people of the same nationality' and, on an even higher level of generalization, that 'The US imperialists and the Soviet revisionists are the biggest tusi [native chieftains] and headmen in the world'! (Yunnan sheng shouci 1969, (25): 6; (126): 4).

When the PFD was terminated and repudiated, as it was in the early 1970s, it left behind a bitter legacy - and not just because of its wholesale rejection of the concept of ethnicity. It was above all the praxis of the PFD that had irreversibly alienated the very people it was supposed to have 'united behind the socialist cause'. More than 45,000 frontier households had experienced 'significant losses of private property' (so the official formulation, used in today's history books) as a result of the cleptocratic approach to collectivization characteristic of the PFD (Yunnan minzu 1994, Vol. 1: 217). Thousands of innocent people had died 'abnormal deaths' - the formulation employed in government records, personnel files and police dossiers to imply but not admit responsibility on the part of the state (Zhao 1986: 37, 224). In villages that had been well below the poverty line to begin with, agricultural production had declined precipitously as the most capable farmers had been stigmatized as 'capitalist forces' and traditional ecological knowledge and techniques been rejected as 'backward, primitive'. More than 50,000 residents of the frontier had left China altogether, seeking refuge with their kinsmen 'of the same nationality' across the border in Vietnam, Laos or Burma. ${ }^{3}$ Public law and order were in disarray. Drug use and drug smuggling - officially all but wiped out in the late 1950s - escalated once more and reached a 20-year high in 1977 (Yunnan shengzhi gonganzhi 1996: 813). Of 
all the different approaches towards the administration of the frontier ever attempted by central, provincial or local governments in Yunnan at one time or other after 1950, none - with the possible exception of the Great Leap Forward - was in the end more disastrously misguided or devastatingly counterproductive than the PFD.

\section{The Cultural Revolution in Yunnan: A New Order}

In Beijing, beginning in the summer of 1966, the Cultural Revolution proceeded in a way that supposedly highlighted the role of the 'popular masses', most notably rebellious 'Red Guard' youths described in Red Flag - the propagandist organ of the CCP Central Committee - as the 'shock force' of the movement, 'cleaning up the muck left over by the old society and sweeping away the rubbish accumulated over thousands of years of history' (Schoenhals 1996: 44). In Yunnan, after an initial period during which the activities of local 'Red Guards' also shaped the progress of the movement, virtually all the political power that mattered came to be concentrated in the hands of the People's Liberation Army (PLA). In March 1967, on orders from the central government in Beijing, a military control commission subordinate to the CCP Committee of the Kunming Military Region (MR) became the highest organ of political authority in the province, assuming temporarily all the powers that at the start of the Cultural Revolution had been vested in the Yunnan People's Committee (i.e. the civilian provincial government) and provincial CCP Committee (Zhongguo gongchandang Yunnan 1994: 223-24). ${ }^{4}$

The creation of a provincial so-called 'Revolutionary Committee' (RC) on 13 August 1968 marked the end of 17 months of direct military rule in Yunnan. ${ }^{5}$ The period during which military rule had been intended as a transition from something old to something new - from a form of government in which Mao Zedong claimed to have lost confidence because of its tendency to 'easily generate feudalistic, revisionist stuff' to a form intended to help 'consolidate and expand the authority of the proletariat' - was over (Mao Zedong sixiang 1968: 283, 345). But the PLA remained predominant as the central government assigned the chairmanship of the Yunnan RC to the concurrent party secretary and political commissar of the Kunming MR, Lieutenant General Tan Furen. Of the four other members of the RC CCP 'nucleus' formed on 23 September 1968, two were lieutenant generals and one was a major general. Unlike some of its nominal counterparts in other provinces, the Yunnan RC was a perfect example of what one Chinese historian has called a 'mutation' of military rule, rather than what Mao Zedong 
was on record as hoping for most of all - 'a government assumed by workers and peasants rising up in revolution' (Wang 1988: 306) (Mao Zedong sixiang 1968: 283).

Yunnan was in a state of extreme social and political tension, as were many other parts of China at this time. ${ }^{6}$ In its Public Notice No. 1, the Yunnan RC blamed the disruption and violence rocking the province on the machinations of a 'tiny handful of class enemies' hell-bent on instigating ordinary citizens to turn against the authorities. It called for an immediate end to what it labelled - in an unusual departure from the normal rhetoric of the times - 'human rights violations (qinfan renquan) by mass organizations' (Relie huanhu 1968: 52). Ominously, it made no mention of the possibility of human rights violations committed by the authorities themselves. Yet when the Yunnan RC at the end of the year embarked on a province-wide movement to 'resolutely and thoroughly flush out class enemies lurking in every corner', it acted with a brutality that made everything the 'masses' or even the 'class enemy' had managed to accomplish up to that point pale by comparison (Kunming nonglin 1969: 248-51). ${ }^{7}$ According to an official estimate, no less than 17,000 persons were killed and 61,000 permanently injured as a direct result of the hard line implemented by the Yunnan RC over the years that followed (Dangdai Zhongguo de Yunnan 1991, Vol. 1: 175). An unofficial estimate by a Chinese historian gives an even more staggering figure, suggesting that 'according to statistics from 1975', the total number of dead exceeded 37,000, while those who suffered imprisonment, torture and injury totalled 300,000 (Yang 1993: 55). ${ }^{8}$

\section{Political Frontier Defence: The Initial Model}

Accounts published in Yunnan in the 1990s hold Lin Biao personally responsible for coming up with the name 'political frontier defence' and - by implication - for sanctioning the particular bundle of policies and practices that it came to designate (Yunnan minzu 1994, Vol. 1: 215). Cultural revolutionary media, too, mention Lin's name in conjunction with the PFD. A propaganda piece from the Guangzhou MR on the heroic exploits of a certain company based on the Hong Kong border relates how it 'successfully implemented in practice Vice-Chairman Lin's important instructions concerning the construction of a political frontier defence' (Jiefangjun bao, 13 September 1968). And a New China News Agency press release about a company in Yunnan refers to it as having 'faithfully implemented Vice-Chairman Lin's instructions on managing the political frontier defence well' (Jiefangjun bao, 8 April 1967). 
Unfortunately, nothing more is known about the precise nature of Lin's 'instructions'. Some of the evidence cited in support of the theory that it was Lin who had come up with the PFD name in August 1966 is spurious. ${ }^{9}$ But there was almost certainly a link between Lin and the PFD, although its exact form remains unknown. From the absence of even a single reference to it in editions of Lin's selected works published in his lifetime and still available in the public domain, one is forced to conclude that the PDF was not central to his political rhetoric. (Equally important, perhaps, is the coincidental absence of any known record linking Mao Zedong or Premier Zhou Enlai personally to the term.)

Whatever the precise background, it is clear that the PFD was closely associated from the outset with the Kunming MR. It was presented in the Liberation Army Daily (Jiefangjun bao) as the Kunming MR Party Committee's contribution to the national plethora of positive models for study and emulation that the media excelled in propagating and it referred specifically to the 'meritorious achievements' of the Third Company of the Kunming MR Fourth Frontier Defence Regiment (a.k.a. the 'Political Frontier Defence Model Company') stationed on the Yunnan-Burma border. When the communist party's Central Military Commission (CMC) in 1967 - for the second time in three years - conferred an honorific title upon the company, its meritorious achievements were said, in short, to consist of the application of Mao Zedong's teachings to the tasks of 'fighting the enemy, defending the frontier and doing work in relation to national minority affairs and building up the border regions' (SCMP 1967, Vol. 3916: 33). The primary achievement that gave rise to the name 'Political Frontier Defence Company' was the one involving the local ethnic minority population. In a rare Englishlanguage dispatch from Kunming entitled 'Red Bastion on Southwest China Frontier', the New China News Agency in April 1967 hinted at what this may have entailed:

[Between 1956 and 1967] the army men called on all the poor families in the area bringing with them Chairman Mao's works. They did innumerable services, big and small, for the people and established a revolutionary friendship with them ... [The] cadres and fighters of the company took Chairman Mao's article 'Analysis of the Classes in Chinese Society' as the key in their work of teaching the people of the various national minorities in the area. Artificial divisions between the nationalities, a legacy from history, were used by the local feudal officials to sow dissension between the army men and the Dai, Jingpo and Lisu people when the Third Company first arrived [in 1956]. Faced with this situation, the army men re-studied Chairman Mao's teaching: 'In the final analysis, national struggle (minzu douzheng) is a matter of class struggle'. (SCMP 1967, Vol. 3917: 28) 
The original context of Mao's 1963 reference to national or ethnic (the Chinese term is the same) struggles as ultimately subordinate to class struggles had been the civil rights movement in the United States (Mao 1966). In 1967, it was re-contextualized to explain what was happening in Dai villages in Southwest China:

The Dai peasants have chosen to remove from their homes the tablets before which they were accustomed to worship gods and the spirits of ancestors. Now they like to have on their walls a picture of the Dai people's beloved leader Chairman Mao. Through studying Chairman Mao's works, the Dai villagers have radically changed their world outlook. Some of them have even become advanced workers. Thousands upon thousands of the Dai, Jingpo and Lisu people enlightened by the penetrating thought of Mao Zedong, came to understand 'Who are our enemies? Who are our friends?' Blazing flames were kindled in their hearts. (SCMP 1967, Vol. 3917: 29)

It is important to note that what is described here in positive terms already represented quite a deviation from the relatively moderate policy that the civilian provincial government had laid down in 1964 and which the central government had approved that same year. The need to distinguish 'friends' from 'enemies' and to replace one's ancestral tablets with pictures of the 'beloved leader Chairman Mao' was in line with a radicalization for which the PLA, more specifically the Kunming $\mathrm{MR}$, and not the nationalities affairs departments of the Yunnan provincial and autonomous prefectural governments, was responsible. In the winter of 1965-66, the MR had endorsed the practice of 'grasping one or two model villages and setting them up as models for emulation' and two years later, with the ascendancy of increasing numbers of military officers to positions of decision-making in the complex area of inter-ethnic relations, the practices associated with the 'model' Third Company of the Fourth Frontier Defence Regiment came to embody all that was 'revolutionary' and hence 'entirely correct' (Yunnan shengzhi: junshizhi 1997: 547). Provincial First Party Secretary Yan Hongyan's warnings of the dangers involved in calling for attacks on 'old habits, old corrupt customs, monks and Daoist priests' in the ethnic minority areas along the frontier had only limited impact (and ultimately contributed to his own downfall in the winter of 1966) (Yunnan minzu 1994, Vol. 2: 159). Instead, in a polemical article on the PFD entitled 'Where is Yunnan Headed III: Do We Want a Production Frontier or a Political Frontier?' a Kunming paper in the spring of 1967 latched on to the word 'political' but discarded the reference to 'defence' in order to maintain that turning all of Yunnan into a 'political frontier' had become the 'glorious and arduous task handed to us by Chairman Mao' (Gongchandang xuanyan, 14 April 1967). 


\section{The Anti-Revisionist Frontiers in 1968: Model becomes Policy}

In the autumn and winter of 1968, after being put in charge of the Yunnan RC, Tan Furen and his fellow officers quickly prioritized the substitution of the PFD for the policies and practices sanctioned by the 'revisionist' regime they had succeeded. The greatest danger at present, Tan stressed, was that of 'rightism' and not 'leftism' (Tan 1974: Section 7: 87 ). In plain speech, in conversations with local leaders during his travels across the province, he elaborated on what this meant and called for an end, once and for all, to the unwarranted 'civility' that supposedly had characterized his predecessors' attitude toward 'class enemies' on the frontier:

It should be a political frontier defence, but what you have here is a civil frontier defence [limao bianfang], a revisionist frontier defence and a peaceful transition [heping guodu] frontier defence. What sort of peaceful transition is that if not one to capitalism? It's the kind of stuff that Liu [Shaoqi] and Yan [Hongyan] practised, with no mobilization of the masses, and no class struggle. [You say you are] afraid of people running away [across the border]: I say, let the bad guys run away and leave it at that! In the frontier areas, how can you possibly concentrate only on raising the cultural level and on production without linking them to the political struggle, to the class struggle? (Ding and Ting 1999: 198-99)

Zhou Xing, the first vice-chairman of the Yunnan RC and former provincial governor, who had spent most of his life in the public security sector, argued that the time had come to dispense with the preferential treatment so far accorded Yunnan's ethnic minority leaders, tusi and 'reactionary headmen':

Whether or not Yunnan can be consolidated and developed depends on how the struggle against the enemy is handled. For one, Yunnan was the last part of the southwest to be liberated. The counter-revolutionaries, dregs of the old society, Chiang Kai-shek's counter-revolutionary court and the reactionary powers of Long Yun and Lu Han all came running here. Furthermore, it was liberated peacefully. Here neither the democratic revolution nor the socialist reform movement was very thorough. Each time an attempt was made, there was this awful fear that it might cause resentment among the tusi or headmen. In actuality, the guiding ideology was that of Liu Shaoqi and Deng Xiaoping, of rightist opportunism, of counter-revolutionary revisionism. It was class reconciliation, motivated by a fear of shaking up the reactionary headmen. (Ding and Ting 1999: 200)

Tan Furen concurred with Zhou and informed lower-level officials that, contrary to what they had been told in the past, the frontier regions were in no way 'special'. There was no reason why they should be 
exempted from the policies and practices that had already been put in effect further inland, in some cases as far back as in the 1950s. A 'class struggle' was now to be launched:

To solve problems in the rural villages, you launch a class struggle. The same applies to the frontier: it is not special in any way. If you don't launch a class struggle, what are the alternatives? First of all, round up all the bad people you've cleansed out, the landlord elements and the rich peasant elements, and concentrate them in a Study Class. Mobilize the masses and have them do it. If land is to be divided up and redistributed, then so be it. If movable [landlord and rich peasant] property is to be divided up and redistributed, then so be it. What is there to be afraid of? Try it in one place first: once you have a precedent, others will follow. All you have to do is get the masses mobilized, then whatever land or grain has to be divided up and redistributed will be divided up and redistributed. Without a class struggle there can be no political frontier defence. (Ding and Ting 1999: 199)10

In the course of being propagated, amplified and exemplified in this way, the scope and intensity of that part of the PFD described as 'doing work in relation to minority affairs' increased significantly. In February 1969, Tan led a delegation from the Kunming MR to Beijing to seek formal approval at the highest level.

Tan was not the only senior PLA officer responsible for a frontier region populated by ethnic minorities who at this point appears to have equated increasingly radical measures with efficient measures. Also visiting Beijing in February 1969 was Lieutenant General Teng Haiqing, Tan's counterpart in Inner Mongolia, and to his subordinates Teng also emphasized that 'the main danger at present' was one of 'rightism' and not 'leftism'. This he did at a time when in Inner Mongolia, more than 250,000 'class enemies' had already been 'uprooted' - the political metaphor that meant on the steppes of Inner Mongolia what 'weeded out' meant in the forests of Yunnan. Only an 'extremely small minority' of these, however, so Teng admitted two months later, were in actuality 'bad people' (Teng et al. 1969).

For all we know, no lessons were drawn from what was happening in Inner Mongolia, where according to Teng, inter-ethnic relations had 'become quite tense' (Teng et al. 1969). On 26 February 1969, the Kunming MR delegation was given a positive hearing by the CMC Office Group - the body under General Huang Yongsheng that had temporarily assumed the functions of the CMC Standing Committee in the wake of the purge of the PLA Acting Chief of Staff, General Yang Chengwu, in 1968. Presumably in part because it was busy monitoring the increasingly tense situation on China's border with the Soviet 
Union - where a violent border clash would erupt on 2 March - and with preparations for the Ninth Party Congress which was to convene on 1 April, the central leadership proposed few if any changes to the PFD as described to them by the Kunming MR. The only criticism they voiced concerned the past:

In the past, the Kunming MR carried out a revisionist line in frontier defence work ... The reactionary feudal tusi and headmen were not attacked, the class demarcation lines were blurred, enemies were not distinguished from friends, and for a long time everything remained in a state of peaceful coexistence. (Yunnan minzu 1994, Vol. 2: 165)

On 21 March, the CMC Office Group circulated the 'Report from the Kunming MR on Intensifying the Frontier Defence Struggle in the Kunming Region' and called for 'intensified PFD construction' (Zhongguo gongchandang Yunnan 1994: 230).

\section{'Five Measures'}

At an ad hoc conference that met from 17 March to 3 April 1969, the Kunming MR CCP Committee and the Yunnan RC decided on the five 'measures' that from now on, with Beijing's approval, would become the key ingredients of the PFD.

The first measure consisted of increasingly uncompromising demands upon the frontier population to manifest, at all times, 'boundless loyalty to Chairman Mao, boundless loyalty to Mao Zedong Thought and boundless loyalty to Chairman Mao's revolutionary line'. An authoritative programmatic document outlining precisely what this was meant to entail had already been disseminated nationwide by the ССР Center in November 1967. Central Document Zhongfa [1967] 350 had described and propagated a number of quasi-religious rituals performed regularly by the officers and men that made up the CCP Politburo's bodyguard, including turning to Mao's portrait in the mornings to ask for 'guidance' and to 'report back' to Mao's portrait in the evenings (Yunnan sheng 1969, Vol. 1: 645-71). At Yunnan's first ever Provincial Congress of Activists in the Living Study and Living Application of Mao Zedong Thought in 1969, one Lisu activist from Eduoluo Production Brigade not far from the Burmese border in Bijiang county described how his kinsmen struggled with this notion of 'loyalty' to Chairman Mao in their daily lives. He quoted a mother of five and the wife of a barefoot doctor as saying: 
In the past, we were the oxen and the horses of the tusi and the headmen. We suffered in misery, most of all because we were powerless. Now Chairman Mao has put the big seal in the hands of us poor and lower-middle peasants, but I still have many selfish thoughts and worry about the number of work points our family is earning. Whenever the old hen has laid a few extra eggs, I forget all about the importance of the big seal. It's all because I've been poisoned by Liu Shaoqi's 'three freedoms and one guarantee' and 'four big freedoms.' I am not being loyal to Chairman Mao. (Yunnan sheng shouci 1969, (25): 5)

The CСP Center did on occasion show signs of a certain ambivalence towards manifestations of 'loyalty' that had a detrimental impact on 'other forms of work'. For example, in June 1969 it noted in Central Document Zhongfa [1969] 33 that 'since old newspapers are by necessity used [for other purposes, e.g. as toilet paper - transl.] and recycled ... they should under normal circumstances not have Chairman Mao's portrait on the masthead' (Yunnan sheng 1969, Vol. 2: 1368). But for a Lisu woman to self-criticize for paying rather more attention to a hen and its eggs than to Mao Zedong thought was quite appropriate.

Measure number two introduced the local content of the nationwide movement to 'cleanse the class ranks'. This movement did not proceeded along identical paths and timelines in all parts of China: so for instance in the national capital, it lasted from January 1968 to May 1969 and, according to official statistics, claimed the lives of 3,731 persons (of these, a staggering 3,512, or 94 percent, were suicides) (Beijing dangshi 1987, Vol. 18: 30). Nationwide, according to one CCP historian, the 'cleansing of the class ranks' resulted in the 'mistaken' persecution of millions (Wang 1988: 299). In Yunnan, it was in the frontier regions actually less an attempt at cleansing any existing 'class ranks' than an attempt at conclusively identifying, for the first time, such ranks. The PFD thus became the vehicle for attempts to assign 'class' categories to a 'residual' segment of the frontier population. That segment comprised some 900,000 or so members of ethnic minorities who in the 1950s had never been formally 'class-ified', but permitted to make what was cryptically referred to as a 'direct transition to socialism'. Also affected were some 1.59 million people who so far had been given only preliminary ('for internal reference') class labels (Ding and Ting 1999: 201).

In the introduction to a Kunming collection of texts on how to carry out the 'cleansing of the class ranks', Mao Zedong was quoted as saying that '[The main purpose of] assigning class status is the cleansing out of bad elements' (Kunming nonglin 1969: 14) and in more than one frontier county this meant that impoverished farmers whose 'loyalty to 
Chairman Mao' was in doubt or who were otherwise deemed 'bad', ran the risk of being given the class status of 'landlord', while rich farmers without an attitude problem just might succeed in attaining the coveted status of 'lower-middle peasant' (Ding and Ting 1999: 203) The name given this voluntaristic practice was that of 'assigning class status by way of a full mobilization of the masses'. It was 'endorsed in principle' by the CCP Center on the condition that a maximum of 8 percent of the total number of ethnic minority households were assigned 'exploiting class' status (Zhonggong zhongyang 1987-98, Vol. 13: 258).

The third measure was the creation of 'People's Communes' along the frontier. In China's inland provinces and elsewhere in Yunnan, People's Communes had constituted the normal form of political and economic organization in the countryside since 1958. Among the ethnic minorities on the Yunnan frontier they had been tried at first, but eventually dissolved as not viable in 1961 (Zhonggong Yunnan 2004: 1- 40). Beginning in late 1966, sporadic attempts had been made locally in the Dai and Jingpo prefecture of Dehong to replace the existing agricultural production co-operatives with the supposedly 'higher' - in the sense of 'more socialist' - form of organization of the Commune. These attempts appear to have been frustrated by the volatility of the political situation, passive resistance on the part of the local population and an exceptionally high local leadership turnover at the time (Yunnan minzu 1994, Vol. 1: 218-19; Vol. 2: 155-57). The establishment of the Yunnan RC in 1968 finally paved the way for the eventual success of a provincial leadership like that of Tan Furen - who almost certainly considered the creation of People's Communes on the frontier as a way of accumulating political capital in Beijing. In neighbouring Tibet, some 150 People's Communes had been established on a trial basis by the end of 1966, and their numbers had been increasing steadily ever since. ${ }^{11}$ In a post-PFD Conference report to the CCP Center on 8 April 1969, Tan's leadership justified 'accelerating the process of creating People's Communes' by highlighting 'the situation at present and the urgent demands put forward by the masses along the frontier' (Yunnan minzu 1994, Vol. 1: 219).

Measure number four was formulated at the time as the mobilization of the masses to politically 'topple and discredit' their tusi and headmen. Economically, the former upper strata of the ethnic minorities were to be deprived of their subsidies, in conformity with the way capitalists and other wealthy 'class enemies' were treated in places like Shanghai, Beijing and Kunming. The tusi and headmen that had taken up residence in Kunming and in prefectural and county government 
seats were to have their urban residence permits withdrawn and they were then to be sent back to their ancestral villages to be 'struggled by the masses'. This practice of repatriation of undesirables from urban to rural areas was common elsewhere in China and had been endorsed by the central authorities on a number of occasions (Yunnan sheng 1969, Vol.1: 296-302). Interestingly enough, Mao Zedong had made vaguely sceptical comments about it in 1966, arguing that it amounted to 'passing a contradiction on to the lower levels to solve, rather than,' as was proper', digesting it oneself' (Zhongyang shouzhang 1967, Vol. 1: 249).

The fifth and final measure was just about the only one that bore a direct relationship to the 'frontier' aspect of the PFD and it called for the identification and unspecified 'thorough weeding out' of the so-called 'nine kinds of persons' among those who had 'returned from abroad ... and their relatives'. The 'returnees' as a distinct category would hardly have existed had it not been for the CCP's attempt, ten years earlier, to enter 'communism'. Between September and November 1958, the so-called 'Great Leap Forward' had made refugees of approximately 110,000 frontier residents who, rather than join in the CCP's saltationist folly, had chosen exile in Vietnam, Laos or Burma. Most of these refugees had returned in 1959 and in the early 1960s and had succeeded in picking up where they had left off, but in the eyes of the authorities they had remained politically suspect ever since (Yunnan minzu 1994, Vol. 1: 190-93).

Given how common references to 'nine kinds of persons' are in the literature that touches upon the PFD in China today, one would have assumed that there is agreement on what the 'nine kinds' actually were. This, however, is not the case. Authors agree that the CCP's five 'classic' 'elements' from the 1950s (i.e. 'landlord, rich peasant, counterrevolutionary, bad and Rightist elements') and 'renegade' and 'special agent' were among the nine, but that is all one can say with certainty. An official history of the CCP in Yunnan gives the final two of the nine elements as 'arch-unrepentant capitalist roaders' and 'active counterrevolutionaries' respectively, while the authoritative Forty Years of Nationality Work in Yunnan gives them as 'arch-unrepentant capitalist roaders' and 'bourgeois reactionary academic authorities' and this latter choice is echoed in a biography of provincial Party Secretary Zhao Jianmin in which 'bourgeois intellectuals' as a term is used as a polite alternative to 'bourgeois reactionary academic authorities' (Zhongguo gongchandang Yunnan 1994: 231; Yunnan minzu 1994, Vol. 1: 217; Ding and Ting 1999: 202). The real original nine categories, however, were 
in fact those mentioned in a resolution passed by Tan Furen's RC at its first plenary session on 19 August 1968. In the resolution, the nine major 'class enemy' categories in Yunnan are listed as 'special agents, renegades, arch-unrepentant capitalist roaders, KMT dregs of the old society and unreformed landlord, rich peasant, counter-revolutionary, bad and Rightist elements' (Relie huanhu 1968: 44). The reason for the apparent confusion more than 30 years later is, of course, that censorship regulations now forbid the use of language such as 'KMT dregs' which is seen as incompatible with united front tactics aimed at improving relations with the KMT and ultimately the 'reunification of the motherland'. Every author has had to find his or her way around the problem of how to mention the unmentionable.

Of these five 'measures' as finalized in April 1969, the first was by its very nature not something that could be 'concluded' at any one point in time, and during the months and years that followed, the deification of Mao waxed and waned with the seasons - high points usually occurring on such auspicious dates as the 1 July and 26 December, the birthdays of the CCP and Mao Zedong respectively. The third measure, the reorganization of the political and economic structure of rural villages and townships, was, on the other hand, a one-off affair. With Baoshan prefecture taking the lead, the 26 counties located on or close to the frontier witnessed the transformation of co-ops and townships into People's Communes in a space of less than three months (Dangdai Zhongguo de Yunnan 1991, Vol. 1: 180). Beginning in the summer of 1969 , the measures that really sustained the PFD were the 'class-ification' of the frontier population and the accompanying degradation and sometime physical elimination of persons 'identified' as enemies of one kind or another.

\section{Phase One: On the Border with Vietnam and Laos}

Local histories published in the 1990s indicate that the PFD came first to the counties located in Diannan, i.e. the southern provincial Military Sub-districts (MSD) of Wenshan, Mengzi and Simao. Here, on the border with Vietnam and Laos, supreme military and political power lay in the hands of PLA units with historical links to Liu Bocheng's and Deng Xiaoping's Second Field Army which had arrived in Yunnan in 1950.

Wenshan MSD responded quickly to the calls emanating from the PFD Conference in March-April 1969 by organizing ad hoc county-level 'Political Frontier Defence Construction Leading Groups'. In Maguan county, right on the Sino-Vietnamese border, one such group organized 
298 military and civilian cadres from the county seat into work teams and dispatched them to eight People's Communes bordering on Vietnam. Nothing is known about the precise nature of the activities of the work teams here, other than that they withdrew amidst celebrations of victory on the eve of Mao Zedong's 77th birthday, in December 1970 (Maguan 1996: 32). However, in Mengzi MSD the activities of similar PFD work teams are fairly well documented. Here violent confrontation between the military and ethnic minority populations ensued within days of the arrival of the first teams. During a visit to Hekou Yao autonomous county, bordering on Maguan, Tan Furen had tried in person to 'foment a class struggle' by challenging the loyalty and political direction of the local population:

Do you have any tusi or headmen here? (People answer: No tusi. There is a retired Mulao headman who lives in the prefectural seat. Nobody in the county seat, though.) In the Cultural Revolution, did you give these people the hard time they deserve? (People answer: Just positive education, not what they deserve.) If you don't give these people the hard time they deserve, even in a Cultural Revolution, then who are you really rebelling against? (Ding and Ting 1999: 200)

Tan's final provocative question backfired, however, when it was accompanied by a ban on the use of the Yao language at meetings and a decree ordering all Yao women to cut their hair and wear 'Han' clothes. When the authorities in the prefectural seat called for the confiscation of all hunting rifles by a certain date, this was widely resisted not only by ordinary villagers - who regarded it as illegitimate interference in their livelihood - but by grass-roots level Yao cadres as well. On 15 April, in Yaoshan People's Commune, more than 3,000 members of the local population fled into the mountains after a bloody confrontation with a PFD work team out to confiscate rifles. When the PLA was called in to 'resolve' this so-called 'counter-revolutionary riot', as it immediately became known, it did so mainly by using its own superior firepower (Yunnan minzu 1994, Vol. 1: 425). In the words of a local history published in the 1980s, 'a number of cadres and masses were erroneously disposed of, and innocent people lost their lives' (Yunnan sheng Honghe 1989: 302).

In Pingbian Miao autonomous county, just to the north of Hekou and not even actually on the border, the PFD turned equally violent. Years later (in 1978) the county party committee issued an official 'reversal of verdicts' in which some of the worst 'excesses' were listed (Pingbian 1990: 187-89). Unfortunately for the historian, the identities of the perpetra- 
tors of those excesses are not identified and precisely what is meant by references to the 'factional followers of Lin Biao and the "Gang of Four" in Yunnan' is unclear. Given the absence of names, one can only assume that the 'they' in the excerpt below refers to PFD work teams made up, at least in part, of PLA officers and men:

Pingbian was [in 1969] designated an 'Artillery Control Area' (paoguanqu) and the Revolutionary Committees throughout the country were all labelled 'hornet nests'. Putting forth the reactionary slogan 'stab open the hornet nest and catch the hornet king alive', they set out to obtain confessions by compulsion, fascist style, and gave them widespread credence. They delivered merciless blows at cadres at all levels and subjected them to brutal persecution. Countless ethnic minority cadres and masses were labelled 'counter-revolutionaries', 'special agent circles', and 'anti-army mutinyprovoking elements'. In the span of only a few months ... some 523 persons were labelled 'special agents' or 'counter-revolutionaries'; altogether 39 were hounded to death (of these, 12 Miao, 4 Zhuang and 7 Yi); and more than 1,730 were hoisted up and beaten, denounced and struggled, forced to wear black signboards around their necks and paraded through the streets. (Pingbian 1990: 187)

In Luchun county, populated mainly by the Hani, Yi and Yao, the PFD was formally launched on 1 May 1969. In the space of 16 months, the PFD as implemented by three consecutive waves of work teams resulted in the identification and 'weeding out' of close to 500 'nine kinds of persons' including 22 previously unidentified landlord elements, 15 new historical counter-revolutionaries and 3 'secret agent suspects'. The number of 'denunciation and struggle' meetings held totalled 783 (Luchun 1992: 40; 468-69).

Simao MSD invented an unusual kind of inter-county 'responsibility system' to execute the tasks that were deemed central to the PFD (Simao 1996, Vol. 1: 43). In Menghai county, located right on the Sino-Burmese border and populated mainly by the Dai, Hani and Lahu, the Revolutionary Committee of Simao prefecture employed such a system by assigning to the Hani autonomous county of Mojiang, located many miles further inland, the task of organizing and sending a 900 person-strong 'Poor and Lower Middle Peasants Mao Zedong Thought Propaganda Team' to Menghai. Either because it was faced with a shortage of genuine 'poor and lower middle peasants' or because it knew conditions in Menghai to be extremely primitive, Mojiang chose to enlist even barbers and cooks on the team. One important difference between the Hani in Mojiang and the Hani in Menghai in this context was that on the Marxist scale of development (as enunciated by the CCP), the Hani in Mojiang were 
more 'progressive' by virtue of practising a 'landlord economy' than their brethren in Menghai who still adhered to a 'feudal suzerain economy' (Dangdai Zhongguo de Yunnan 1991, Vol. 2: 219-20). The Mojiang team joined some 3,100 local PLA officers and state farm cadres in what at the time was called simply 'going to the frontier to catch enemies' (Yunnan minzu 1994, Vol. 1: 218). In 1969, throughout Menghai county, according to an official chronology published in 1997, persons classified as 'problematic landlord elements, rich peasant elements, reactionary elements, bad elements or Rightist elements' were rounded up in concentration camps and forced to labour under the supervision of armed militia. The number of 'unjust, false and mistaken cases' that this occasioned in the end totalled more than 2,000 (Menghai 1997: 17).

In Jiangcheng Hani autonomous county, on the border with Laos and Vietnam, a similar 'responsibility system' was employed, this time involving the inland Hani and Lahu autonomous county of Zhenyuan. Zhenyuan, too, was more 'progressive' (in Marxist terms) than its sister county on the frontier, as far as the economic development of the resident Hani population was concerned (Dangdai Zhongguo de Yunnan 1991, Vol. 2: 219-20). From Zhenyuan, more than 700 persons were dispatched to Jiangcheng to augment what was seen as an insufficient number of persons that could actually be 'relied upon'. The following details of the PFD in Kangping People's Commune, Jiangcheng, were published in an official history in the late 1980s:

The 'Political Frontier Team' employed torture to extract a confession from a Baka Production Team member who, after having had an illicit affair with someone whose spouse was a member of the PLA, had attempted to escape [across the border]. They kept on beating him until the blood gushed forth from his nose and mouth. They refused to stop until they were satisfied they had the 'political background' of his attempted escape. With the help of confessions extracted through torture and intimidation, they came up with the existence of a 'secret counter-revolutionary organization with illicit foreign links' in Baka. Of the total 26 households in the production team, 23 were said to be involved. The savage and ferocious methods employed by the 'Political Frontier Team' were so bad that for a long time, the peasants in Baka were subject to a fascist dictatorship. During the day, they were not permitted to come into contact with each other, and at night no visits between households were allowed. There were sudden household searches, and if the peasants were slow in opening their doors [to the search parties] the doors would be smashed with stones or rifle butts, or pried open with knives ...

In addition to slapping their targets in the face while forcing them down on their knees, the [Political Frontier Team] also dipped people's hair in 
kerosene and then set it aflame, scorched people's buttocks with firewood and staged fake executions. There were altogether 32 able-bodied men in the production team, and of these 28 were investigated. Seven were subjected to cruel torture, as a result of which three were crippled and one died. (Jiangcheng 1989: 269-70)

Jiangcheng also witnessed the enforced rural resettlement of 'urban' residents of allegedly 'bad' class background. Once it had been determined that they were unsuited to remain in the townships of Jiangcheng, such people were forcibly dispatched to the countryside to 'labour under the supervision of the masses' (Jiangcheng 1989: 269-70).

In Lancang Lahu autonomous county, a total of 2,291 households spread out over 13 People's Communes had their homes raided and possessions valued at altogether 487,836 Yuan confiscated by a work team comprising more than 1,000 locals and outsiders dispatched from Simao (Yunnan minzu 1994, Vol. 1: 217) (Lancang 1996: 457). Neighbouring Ximeng Wa autonomous county (one of the smallest counties in all of Yunnan), contemporary sources tell us, was the home of one of the best-known PFD 'model units' - New Little Hamlet, a.k.a. the Red Flag Production Team of the Red Flag Production Brigade of the Red Flag People's Commune. Here, in the spring of 1970, the 'revolutionary masses' were ordered to learn from New Little Hamlet's 'Red Flag People's Militia Platoon' and its exemplary courage in repelling incursions across the Burmese border by 'KMT dregs of the old society' (Yunnan sheng shouci 1969 (126): 2-6; Yunnan sheng 1973, Section 6: 26). Today's accounts highlight a different facet of the PFD in Ximeng: here and in three neighbouring counties it claimed the lives of a total number of 718 people 'due to abnormal causes' (Yunnan minzu 1994, Vol. 1: 217). In the same counties, 3,950 households had greater or lesser parts of their property confiscated. The 212 richest households had residential property totalling 8,865 square meters confiscated, estimated at 554,000 Yuan in value, together with other valuables (rice, draught animals, cash, furniture, work points, etc.) estimated at 688,300 Yuan (Simao 1996, Vol. 2: 33).

\section{Phase Two: Western Yunnan}

What could be learnt from the first year of the PFD in Diannan was a topic high on the agenda of a meeting convened by the Yunnan RC and Kunming MR in Lancang Lahu autonomous county in the final days of March 1970. In the wake of the meeting, the provincial civilian and military media called on political and military leaders at all levels to 
make PFD 'construction' a central aspect of their day-to-day work. In response to an inquiry from the CMC Office Group into why some areas were lagging behind, the Yunnan RC and Kunming MR dispatched 52 work teams to 39 different pilot units to 'aid' those areas in 'identifying discrepancies and clarifying directions' (Yunnan minzu 1994, Vol. 2: 16668). The result was a further intensification of the PFD that impacted on Dianxi (the western provincial Military Subdistricts of Baoshan, Lijiang and Lincang) where, judging from the available sources, the high tide of the PFD on the whole occurred later than in the south.

An official chronology, published in 1995, of Tengchong county - located in the Baoshan MSD - does not mention the PFD in any of its entries for 1969. In September 1970, it states, teams of cadres were dispatched from the county seat to rural People's Communes to engage in PFD 'construction', and the outcome was 'no small number of unjust, false and mistaken cases' (Tengchong 1995: 40). In Ruili, the PFD resulted in the departure - across the border into Burma - of over 4,000 frontier residents in the winter of 1969-70. This was in no small part almost certainly due to the fact that they had been forcibly 'liberated' from their property. This is how one source describes what happened:

In some counties ... the raids on people's homes were carried out in one of two ways. One way of doing it was to gather together a bunch of people who waving red flags, carrying portraits of Mao Zedong and shouldering Mao Zedong quotation boards, would approach the family home about to be raided. Once in place they would order the entire family out and force it to kneel in front of the house. Hereupon a bunch of people would enter the home to pick out everything of any value and cart it off. Another way of doing it was simply to order the family to abandon their home or to drag them off elsewhere and then enter by force, smash up the place and remove all valuables. (Ding and Ting 1999: 204)

Suddenly faced with a depopulated border, the authorities in Baoshan arranged for 1,100 'poor and lower middle peasants' from counties further inland to reclaim and settle down in the deserted frontier villages. Eventually, their families followed and they officially assumed the status of resettled farmers (Ruili 1996: 48).

An official history of Luxi county, published in 1993, makes reference to the use of over one hundred different forms of torture to extract confessions from victims of the PFD and the 'One Hit Three Anti' campaign that was carried out simultaneously:

Tasks in a variety of areas were merged, and reckless denunciations and indiscriminate attacks occurred all over the place. A total of 3,271 persons (239 
of them cadres, the rest just ordinary commune members) were investigated as part of some 304 unjust, false and mistaken cases that ultimately resulted in the implication of close to ten thousand people. In attempts to extract confessions by force, more than a hundred different forms of cruel fascist torture were employed, e.g. hanging a steel ring (gua gangquan), stepping on a pole (cai gangzi), capping with leaf lard (kou banyou), monkey moves the stake (houzi ban zhuang) and binding the head with iron wire (tiesi gutou). As a result, a total of 219 persons were persecuted to death and died of unnatural causes, and more than five hundred persons were crippled or injured from horrible torture. (Luxi 1993: 251)

A total of 1,838 fairly well-to-do households in Luxi were formally classified as 'rich peasants' or as otherwise belonging to the 'antagonistic' classes. The result of all this was a mass exodus of over 5,100 refugees, most of them - the county history suggests - fleeing across the border to Burma.

In Lushui county, Lijiang MSD, the PFD was not initiated until 1970. In April of that year, an official history states, three waves of work teams were sent to 142 mountain hamlets located on the border with Burma. The outcome of their activities included among other things 'numerous shocking incidents of "espionage cases", "radio transmitter cases", "treason and join the enemy cases", and "illicit overseas contacts cases"' (Lushui 1995: 22). In Gengma Dai and Wa autonomous county in Lincang MSD, the PFD involved the 'class-ification' of persons who up to this point had not been 'class-ified', and the confiscation and redistribution according to 'class' criteria of 'excessive' private property, including residential space (Gengma 1995: 29). (By the end of 1970, policy documents drawn up elsewhere in the Kunming MR mentioned specifically that confiscated property should 'no longer be distributed to the poor and lower-middle peasants', thus suggesting that the practice up until then must have been quite common (Dangdai Guizhou 1996: 341)).

In the final days of October 1970, a meeting to 'exchange experiences' from the PFD in Dianxi was convened jointly by the Yunnan RC and Kunming MR. The meeting ended up affirming what had been achieved so far and laid out plans for how the PFD could be further 'deepened' (Yunnan minzu 1994, Vol. 2: 169). The sudden death of Tan Furen on 17 December 1970 (allegedly murdered by one of his own body-guards) did not provoke any major changes as far as the PFD was concerned (Ding and Ting 1999: 280). On 22 February 1971, the State Council and CMC called on Yunnan to 'put all frontier defence work onto the track of giving compulsory prominence to proletarian politics' (Zhenkang 1992: 39). What this hyper-jargonized order meant in plain language was tacit 
endorsement. Whereas it had indeed been possible - not to say probable - that the PFD was perceived initially simply as yet another political 'movement' and as such involving the mere temporary suspension of the laws, norms and rules that applied at 'regular times', it had by now assumed all the features of something permanent. In response to the State Council and CMC, 219 senior military and civilian officials in Yunnan involved in the PFD vowed at a special conference in April 1971 to:

put a major effort into achieving some major visible achievements and be able within three years or so to further reinforce the proletarian dictatorship in the Yunnan frontier region (the counties and [market] towns (zhen) directly on the border), consolidate and develop the socialist economy and build it into a consolidated PFD under unified party leadership with the armed forces as the backbone and the broad masses as the foundation. (Yunnan minzu 1994, Vol. 2: 171)

But then something happened in the national capital.

\section{More Harm than Good? - Abandoning the PFD}

In July 1971, what in retrospect must be considered a crucial report was passed on to China's Premier Zhou Enlai by Major General Li Desheng, a Long March veteran and one-time Second Field Army officer appointed to the CMC Office Group in 1969. The report stated in euphemistic but clear prose that the 'class-ification' of the ethnic minority population in Yunnan that was such a central part of the PFD had produced 'side-effects', i.e. was doing more harm than good. Upon reading the report - which mentioned the Dai and the Yao specifically - Zhou wrote a letter to Mao Zedong, Lin Biao and the members of the CCP Politburo in which he dispensed with euphemisms and maintained that 'the state of affairs is extremely serious on the frontier and in the ethnic minority areas'. Given, he said, that 'we have already been made aware of the seriousness of the situation', the matter should be put on the Politburo agenda. In preparation for 'a serious discussion' by the Politburo, investigators should be sent to the area to confirm the accuracy of the report (Zhonggong zhongyang 1997, Vol. 3: 470).

Two Politburo meetings (neither of which was likely to have discussed the report) later, on 24 August 1971, Mao signed off Central Document Zhongfa [1971] 51 which called for a reassessment of the practice of 'classifying' the ethnic minority population in key strategic areas (Zhonggong zhongyang 1997, Vol. 3: 470-77; Zhonggong zhongyang 1987-98, Vol. 13: 258-59). An inquiry was to be launched - but no clear indication was given as to what its findings were expected to be and as a result, it 
made little progress at first. It took the political demise of Lin Biao and his generals in the winter of 1971 before politicians so inclined were in a position to devise effective strategies for questioning and ultimately abandoning the PFD. Now there was someone to blame.

In February 1972, exactly three years after their first visit to Beijing to outline the PFD and have it endorsed by the central authorities, senior officials from the Kunming MR were once again in the national capital, this time to face the criticisms of a reorganized CMC leadership. According to Marshal Ye Jianying and Vice-Premier Li Xiannian, frontier defence work had to be 'carried out in accordance with Chairman Mao's teachings' and this, it was understood, had not been the case in recent years. Instead, 'Great Han Chauvinism' had developed and 'ethnic minority cadres and masses' had been discriminated against (Zhongguo gongchandang Yunnan 1994: 247). As a first step toward rectifying this deplorable situation, the central authorities reiterated their call for an inquiry - but this time with the clear mandate of substantiating an official line on the deceased Lin Biao which had it that:

Lin Biao and his ilk talked a lot about a 'political frontier defence' but in reality peddled their landlord bourgeois politics, wrecked the party's nationality policy, wrecked economic construction on the frontier and attempted in vain to create chaos on the frontier. (Wang 1975, Section 7: 77)

In March and April, six teams of investigators from the Kunming MR $\mathrm{CCP}$ Committee and Yunnan RC descended on the frontier counties of Ruili, Ximeng, Mengla and Cangyuan and the prefectures of Honghe and Chuxiong. At the end of April and in the first half of May, their findings were presented and discussed at a series of meetings attended inter alia by ethnic minority cadres (Yunnan minzu 1994, Vol. 2: 173).

The meetings produced two reports. One went up the bureaucracy to the central party, government and military authorities and described the situation in ethnic minority affairs with suggestions for change and improvement. The other report went down the bureaucracy, to party committees on the county and regiment level, and it contained some tentative opinions on how 'ethnic minority work can be strengthened'. Administrative reforms were proposed and eventually undertaken, including the re-empowerment of the ethnic autonomous prefectural governments of Xishuangbanna, Dehong, Diqing and Nujiang, all of which had been rendered powerless and de facto abolished in the wake of the creation of the Yunnan RC. On orders from the central government, PLA officers began a phased withdrawal from RCs all across China: on the Yunnan frontier, this 'demilitarization' began with the appointment of a 
civilian party official to the chairmanship of the Lincang RC in August 1972 (Zhongguo gongchandang Yunnan 1994: 238, 248). In January 1973, a Yunnan Nationalities and Frontier Work Commission was set up to act as an executive organ of the provincial RC. Although led by a PLA officer for the first three years of its existence, its mere existence signalled the beginning of a new era.

On 14 August 1972, the Kunming MR Political Department decreed for the first time that the PFD had not merely been distorted by 'Lin Biao and his ilk' but had itself been an 'erroneous long-term policy' touted by Lin that had to be thoroughly repudiated and condemned. In its stead, new policies and practices were to be worked out on the basis of Mao Zedong's instructions from 1963 on how to prevent 'revisionism' from impacting on the situation in China's frontier regions (Yunnan minzu 1994, Vol. 2: 174). The gist of those instructions had been that economic development was an indispensable weapon in the fight against deviations from socialism (Zhonggong zhongyang 1987-98, Vol. 10:378-79). As such, they pointed in a very different direction from the CCP Chairman's 1963 comment on the US civil rights movement that had provided the ideological justification for the PFD.

A final high point in the repudiation of the PFD occurred during the 1973 National Land Border Defence Conference. In the wake of that conference, in September 1973, the Kunming MR convened a special 'Frontier Defence Politics [sic] Work Conference' at which the 'strategic significance of doing a good job of nationalities work on the frontier' was reaffirmed (Yunnan shengzhi junshizhi 1997: 543). Whereas speaking of 'frontier defence politics' (bianfang zhengzhi) was still OK, to use the formulation (tifa) 'political frontier defence' in any positive sense was by now impossible. So tainted with negative connotations had it become that by the end of the 1970s the 'Political Frontier Defence Model Company' on the Yunnan-Burma border had to be officially redesignated the 'Red Bulwark Frontier Defence Company No. 3' by the Central Military Commission (Zhongguo gongchandang Yunnan 1994: 550). Practically, ideologically and finally linguistically, the era of the PFD had come to an end.

\section{Conclusion: Explaining what Happened}

To borrow a key concept from the Yunnan RC's Public Notice No. 1, the PFD ended up perpetrating countless 'human rights violations'. An obvious challenge facing the historian is to find a mode of exposition that not only allows one to describe those violations but also to explain, 
if only provisionally, why they occurred. With this aim in mind, ought not the history of the PFD perhaps best be told as an ethnic conflict in which the adversaries are the 'Han Chinese' on the one side and 'minorities' on the other? Such a description would allow for a clear-cut story line (structured as a tragedy) and provide a compelling, 'politically correct' answer to the question 'Why?' by evoking the pre-existing and culturally near-universal archetype of David vs. Goliath. But it would necessitate tinkering with the evidence. Certain facts would have to be adjusted in order to reconstruct a past the reality of which would thereby be rendered inauthentic. The example of the Simao MSD shows that it was not the Hani per se that became targets of the PFD but the Hani on the frontier. The supposedly progressive Hani further inland were enlisted by and joined the perpetrators. At least one PFD 'model unit' was made up entirely of Wa militia men (who together with the PLA denounced the pre-1968 frontier defence of 'civility') (Yunnan sheng shouci 1969, (126): 3 ).

A different explanation - one that elucidates more by formal argument than by emplotment - pits China's armed forces against the civilian population. This explanation is supported by the facts as known, as well as by the CCP leadership's metonymical conceptualization of the relationship between the army and the state. At a plenum of the CCP Central Committee in October 1968, Lin Biao had declared in his ty pical, rambling style: 'Recently Chairman Mao has been emphasizing over and over again - and this is furthermore entirely in line with MarxismLeninism and the Chairman's own thinking - that what is clear is that, frankly speaking, essentially speaking, the so-called state is primarily the army' (Lin Biao 1968: 5). With the army thus already representing 'in essence' the state, this explanation - with the help of a second metonymical manoeuvre on the part of the historian involving the no less 'essential' substitution of society for the civilian population - allows for congruence with the best accounts of what took place elsewhere in China in the 1960s. If the Cultural Revolution was the ultimate confrontation between the PRC state and civil society in general, then the PFD was a special but not a unique case, a derivation that pitted the central state against peripheral society, civil or not civil.

It is important in this context to bear in mind where in the state administrative structure the PFD policy came into being. As Katherine Palmer Kaup pointed out in a study of the Zhuang in Yunnan and Guangxi, past discussions of ethnic mobilization and nationality issues in the PRC have tended to 'under-examine' state structures. China may 
be a unitary state, she noted, 'but centrally determined policy is implemented by authorities within territorial administrative structures' and even though 'there has been a great deal of attention devoted to "state policy" in the literature, the state and the centre have generally implicitly been conflated into a single monolith or otherwise been imprecisely differentiated' (Palmer Kaup 2002; 864-65). In the case of the PFD, the role of armed forces and the supra-provincial Kunming MR leadership backed by members of the CMC far outweighed in importance whatever input might have originated with remnants of the localized 'civilian' party and state apparatuses, all but completely destroyed in the first year of the Cultural Revolution.

To the extent that it was a brutal confrontation between the central state and peripheral society, was the PFD also a case of Chinese state expansion into the southwest frontier? Not in the common sense of a move to assert control over new or contested territory - such expansion had already been concluded by 1961. The frontier territory was by 1969 a part of China. But was it a part of the 'new, socialist People's China'? That was in the eyes of many an altogether different question, and very much an open one. In the early 1960s, the term 'empty areas' referred in Yunnan not primarily to sparsely populated sectors of the frontier but to places where there was as yet no 'people's political power'. In view of this, the argument could be made that the PFD was indeed a form of state expansion. Such an argument, of course, would necessitate a definition of the state in cultural or ideological terms rather than in Realpolitik terms, a definition possibly less alien to the Chinese than to a 'westerner'.

This begs the final question: whether or not the PFD can meaningfully be considered as a part of the great 'civilizing project' in which successive governments of China have reputedly been engaged for centuries. It would be hard indeed to characterize the story told in this paper as one of 'civilization'. In actuality, as this paper has tried to illustrate, it was a great barbarizing project. As such, it spoke volumes about the relationship between state and society in Mao's China. And not the least for that reason, it deserves to be accorded far more than a peripheral place in the tragic history of the Cultural Revolution.

Dr Michael Schoenhals is Associate Professor (Docent) with a focus on modern Chinese society, in the Department of East Asian Languages, Lund University. 


\section{NOTES}

1 Research for this paper was supported by a grant from the Swedish Research Council (VR).

2 This aspect of the Cultural Revolution was in no way limited to Yunnan but a general one wherein 'cultural uniqueness' ceased to be a 'valid basis for claims to particular treatment' (Schein 2000: 86, 144).

3 In the Cultural Revolution, similar departures en masse across the national border were sometimes rumoured to be in the offing, in other parts of China, but did not always materialize (Pang 1998: 154).

4 The Kunming MR encompassed the Yunnan and Guizhou Military Districts (sheng junqu).

5 The key texts documenting the creation of the Yunnan Revolutionary Committee are to be found in Relie huanhu (1968).

6 Compare, for example, the analysis of turmoil and violence in rural southern China in Unger (1998).

7 Official estimates of the total number of persons whose 'abnormal deaths' (fei zhengchang siwang) between April 1967 and August 1968 may be attributed to armed clashes between different segments of the civilian population are somewhere in excess of 5,000 (Zhongguo gongchandang Yunnan 1994: 231; Dangdai Zhongguo de Yunnan 1991, Vol. 1: 174).

8 A methodologically sophisticated estimate of national-level casualty figures is to be found in Walder and Su (2003).

9 E-mail from $\mathrm{Dr} \mathrm{Du} \mathrm{Pu}$, senior researcher with the Contemporary China Research Institute, Beijing, 2 March 2000.

10 Yunnan's prefectural and county-level 'Study Classes' had been the subject of a minor nationwide emulation drive in the winter of 1967-68 (Yunnan sheng shouci 1969 (1): 632-38).

11 By 1970, there were more than 1,200 People's Communes in Tibet (Dangdai Zhongguo de Xizang 1991, Vol. 1: 385-86).

\section{REFERENCES}

Barnouin, Barbara and Yu Changgen 1993. Ten Years of Turbulence: The Chinese Cultural Revolution. London: Kegan Paul International.

Beijing dangshi ziliao tongxun [Beijing Party History Newsletter].

Dangdai Guizhou dashiji 1949-1995 [Record of Major Events in Contemporary Guizhou 1949-1995] 1996. Guiyang: Guizhou renmin chubanshe.

Dangdai Zhongguo de Xizang [Contemporary China's Tibet] 1991. 2 vols. Beijing: Dangdai Zhongguo chubanshe.

Dangdai Zhongguo de Yunnan [Contemporary China's Yunnan] 1991. 2 vols. Beijing: Dangdai Zhongguo chubanshe.

Ding, Longjia and Ting Yu 1999. Kang Sheng yu 'Zhao Jianmin yuanan' [Kang Sheng and the 'Unjust Case of Zhao Jianmin']. Beijing: Renmin chubanshe.

Gengma Daizu Wazu zizhixian zhi [History of Gengma Dai and Wa Autonomous County] 1995. Kunming: Yunnan minzu chubanshe.

Gongchandang xuanyan [The Communist Manifesto]. Note: tabloid published in Kunming. 
Jiangcheng Hanizu Yizu zizhixian zhi [History of Hani and Yi Jiangcheng Autonomous County] 1989. Kunming: Yunnan renmin chubanshe.

Jiefangjun bao [Liberation Army Daily].

Kunming nonglin xueyuan geming weiyuanhui zhengxuanzu (ed.) 1969. Qingli jieji duiwu ziliao huibian [Collected Materials on Cleansing the Class Ranks]. Kunming.

Lancang Lahu zu zizhixian zhi [History of Lancang Lahu Autonomous County] 1996. Kunming: Yunnan renmin chubanshe.

Lin, Biao 1967. Lin Biao wenxuan [Lin Biao Selected Works]. Beijing. Publisher unknown.

-1968. 'Zai Zhonggong 8 jie kuoda de 12 zhong quanhui di 2 ci huiyi shang de jianghua' [Speech at the Second Meeting of the $12^{\text {th }}$ Plenum of the $8^{\text {th }}$ Central Committee] 26 October. Original CCP Central Committee General Office transcript in the possession of the author.

Luchun xianzhi [History of Luchun County] 1992. Kunming: Yunnan renmin chubanshe.

Lushui xianzhi [History of Lushui County] 1995. Kunming: Yunnan renmin chubanshe. Luxi xianzhi [History of Luxi County] 1993. Kunming: Yunnan jiaoyu chubanshe.

MacFarquhar, R. and J. K. Fairbank (eds) 1991. The Cambridge History of China, Vol. 15. The People's Republic, Part 2: Revolutions within the Chinese Revolution. Cambridge: Cambridge University Press.

Mackerras, Colin 2003. 'Ethnic Minorities in China.' In Colin Mackerass (ed.), Ethnicity in Asia. London: RoutledgeCurzon: 15-47.

Maguan xianzhi [History of Maguan County] 1996. Beijing: Sanlian shudian.

Mao Zedong sixiang wansui [Long Live Mao Zedong Thought] 1968. N.p.

Mao, Zedong 1966. 'Statement Supporting the American Negroes in their Just Struggle against Racial Discrimination by U.S. Imperialism.' Peking Review 33: 12-13.

Menghai xianzhi [History of Menghai County] 1997. Kunming: Yunnan renmin chubanshe.

Palmer Kaup, Katherine 2002. 'Regionalism versus Ethnic Nationalism in the People's Republic of China.' The China Quarterly 172: 863-84.

Pang, Keng-Fong Pang 1998. 'Unforgiven and Remembered: The Impact of Ethnic Conflicts in Everyday Muslim-Han Social Relations on Hainan Island.' In William Safran (ed.), Nationalism and Ethnoregional Identities in China. London: Frank Cass: 142-62.

Pingbian Miaozu zizhixian minzu zhi [Ethnic History of Pingbian Miao Autonomous County] 1990. Kunming: Yunnan daxue chubanshe.

Relie huanhu Yunnan sheng geming weiyuanhui chengli [Hail the Creation of the Yunnan Revolutionary Committee] 1968. Kunming: Yunnan renmin chubanshe.

Ruili shizhi [History of Ruili Municipality] 1996. Chengdu: Sichuan cishu chubanshe.

Schein, Louisa 2000. Minority Rules: The Miao and the Feminine in China's Cultural Politics. Durham: Duke University Press.

Schoenhals, Michael (ed.) 1996. China's Cultural Revolution, 1966-1969: Not a Dinner Party. Armonk: M. E. Sharpe.

Simao diqu zhi [History of Simao Prefecture] 1996. 2 vols. Kunming: Yunnan minzu chubanshe.

Survey of China Mainland Press (SCMP).

Tan, Furen 1974. 'Zai Kunming junqu san da jiguan quanti ganbu huiyi shang guanyu kaiban Mao Zedong sixiang xuexiban de dongyuan baogao' [Mobilization Report to Launch a Mao Zedong Thought Study Class at a Gathering of All Cadres in the Three Big Departments of the Kunming MR]. Zhonggong nianbao 1973 [Chicom Yearbook 1973]. Taibei: Zhonggong yanjiu zazhi she.

'Teng Haiqing, Wu Tao, Li Shude san tongzhi de jiancha' [Self-criticisms by the Three Comrades Teng Haiqing, Wu Tao, and Li Shude] 19 April 1969. Unpublished, copy in possession of the author.

Tengchong xianzhi [History of Tengchong County] 1995. Beijing: Zhonghua shuju. 
Unger, Jonathan 1998. 'Cultural Revolution Conflict in the Villages'. The China Quarterly 153: 82-106.

Walder, Andrew G. and Yang Su 2003. 'The Cultural Revolution in the Countryside: Scope, Timing and Human Impact'. The China Quarterly 173: 74-99.

Wang, Bicheng 1975. 'Zai Yunnan shengwei he Kunming junqu dangwei ganbu xuexiban jieshu shi de jianghua' [Talk at the Conclusion of the Yunnan Provincial Party Committee and Kunming Military Region Party Committee Cadres' Study Class]. Zhonggong nianbao 1974 [Chicom Yearbook 1974]. Taibei: Zhonggong yanjiu zazhi she.

Wang, Nianyi 1988. Da dongluan de niandai [Years of Great Turmoil] Zhengzhou: Henan renmin chubanshe.

Yan, Jiaqi and Gao Gao 1996. Turbulent Decade: A History of the Cultural Revolution. Honolulu: University of Hawai'i Press.

Yang, Jian 1993. Wenhua dageming zhong de dixia wenxue [Underground Literature in the Great Cultural Revolution]. Beijing: Chaohua chubanshe.

Yunnan minzu gongzuo sishi nian [Forty Years of Nationality Work in Yunnan] 1994. 2 vols. Kunming: Yunnan minzu chubanshe.

Yunnan sheng geming weiyuanhui (ed.) 1969. Wuchanjieji wenhua dageming wenjian huibian [Collected Documents from the Great Proletarian Cultural Revolution]. 2 vols. Kunming.

Yunnan sheng geming weiyuanhui, Kunming junqu 1973. 'Guanyu kaizhan xiang Xiaoxinzhai "Hongqi minbingpai" xuexi huodong de tongzhi' [Circular on Launching Activities to Learn from New Little Hamlet's 'Red Flag Militia Platoon']. Zhonggong nianbao 1972 [Chicom Yearbook 1972]. Taibei: Zhonggong yanjiu zazhi she.

Yunnan sheng Honghe Hanizu Yizu zizhizhou minzu zhi [Ethnic History of Honghe Hani and Yi Autonomous Prefecture in Yunnan] 1989. Kunming: Yunnan daxue chubanshe.

Yunnan sheng shouci huoxue huoyong Mao Zedong sixiang jijifenzi daibiao dahui fayan cailiao [Speeches at the First Yunnan Provincial Congress of Activists in the Living Study and Living Application of Mao Zedong Thought] 1969. Kunming, November 1.

Yunnan shengzhi: gonganzhi [History of Yunnan: Public Security History] 1996. Kunming: Yunnan renmin chubanshe.

Yunnan shengzhi: junshizhi [History of Yunnan: Military History] 1997. Kunming: Yunnan renmin chubanshe.

Zhao, Qizheng 1986. Ganbu renshi gongzuo shouce [Cadre Personnel Work Handbook]. Shanghai: Shanghai renmin chubanshe.

Zhenkang xianzhi [History of Zhenkang County] 1992. Kunming: Yunnan renmin chubanshe.

Zhonggong Yunnan shengwei dangshi yanjiushi and Yunnan sheng dang'anguan (eds.) 2004. 'Dayuejin' yundong: Yunnan juan [The 'Great Leap Forward' Movement: The Yunnan Volume]. Beijing: Zhonggong dangshi chubanshe.

Zhonggong zhongyang wenxian yanjiushi (eds) 1987-98. Jianguo yilai Mao Zedong wengao [Manuscripts of Mao Zedong since the Founding of the Nation] 13 vols. Beijing: Zhongyang wenxian chubanshe.

- 1997. Zhou Enlai nianpu 1949-1976 [Zhou Enlai Chronology 1949-1976] 3 vols. Beijing: Zhongyang wenxian chubanshe.

Zhongguo gongchandang Yunnan sheng zuzhi shi ziliao Yunnan sheng zheng jun tong qun zuzhi shi ziliao 1926.11-1987.10 [Materials on the History of the CCP Organization, Government, Military, United Front, and Mass Organizations in Yunnan Province 1926 November to 1987 October] 1994. Beijing: Zhonggong dangshi chubanshe.

Zhongyang shouzhang jianghua [Central Leaders' Speeches] 1967. 4 vols. Beijing: Boli zongchang. 